\title{
Vestibular papillomatosis mimicking genital warts in a pregnant woman
}

\section{Gebe kadında genital siğili taklit eden vestibuler papillomatozis}

\section{Atiye Oğrum, ๑ Hatice Yılmaz Doğru*}

Tokat Gaziosmanpașa University Faculty of Medicine, Department of Dermatology and Venereology; *Department of Gynecology and Obstetrics, Tokat, Turkey

\begin{abstract}
Vestibular papillomatosis (VP) is considered as an anatomical variant of vulva and suggested as counterpart of pearly penile papules in males. The condition, approximately present in about $1 \%$ of women, is characterized by pink, smooth, small papules located around the labia minor and vaginal introitus. Although it usually shows no symptoms, some women suffer from complaints such as itching, burning, sensitivity, and pain. Despite human papillomavirus has been accused in the etiology, no outcomes are found to support this association. The similarity of VP to genital warts leads to unnecessary examinations and treatments, thus causing anxiety in patients. Here, we present a case with 37 weeks of pregnancy, who is planned to undergo cesarean section due to diagnosis of genital warts.

Keywords: Vestibular papillomatosis, vulvar vestibular papillomatosis, pregnancy, genital warts

\section{Öz}

Vestibuler papillomatozis (VP), vulvanın bir anatomik varyantı olarak kabul edilmekte olup, erkekteki penil incimsi papülün kadındaki karşıllğı olduğu düşünülür. Kadınların yaklaşık \%1'inde görülmekte olup, labia minör ve vajinal introitus çevresinde yerleşen küçük, pembe, yumuşak papüllerle karakterizedir. Genellikle semptom oluşturmamakla birlikte, bazı kadınlar kaşıntı, yanma, hassasiyet ve ağrı gibi şikayetlerden yakınırlar. Etiyolojisinde insan papillomavirüs suçlanmakla birlikte, bu ilişkiyi destekleyen bulguya rastlanmamıștır. VP ve genital verrü benzerliği nedeniyle yapılan gereksiz inceleme ve tedaviler hastalarda anksiyeteye neden olabilir. Burada, genital verrü tanısı nedeniyle sezaryen ile doğum planlanan 37 haftalık gebe kadın sunuldu.

Anahtar Kelimeler: Vestibuler papillomatozis, vulvar vestibuler papillomatozis, gebelik, genital siğil
\end{abstract}

\section{Introduction}

Vestibular papillomatosis (VP) is the benign, asymptomatic, anatomical variant of vulvar epithelium 1 . The prevalence is $1-33 \%$ with the highest between 21 and 56 years at reproductive ages ${ }^{1-4}$. Though human papillomavirus (HPV) is claimed as the causative agent previously, now VP is considered a benign entity with no connnection with HPV5-8.
Regarding with the highest prevalence in reproductive age, the ratio of the occurrence or diagnosis during pregnancy is very high. In pregnant women, misdiagnosis of these harmless lesions as genital warts may lead to cesarian section, because of the risk of laringeal papillomatosis in infants born vaginally to mothers with active HPV infection. This condition can cause complications associated with invasive interventions and delay in the connection of the mother with

*This case was presented as an oral presentation at the IDEA (International Dermatology \& Dermatopatology \& Esthetics Academy) 2018 Congress in Ankara, Turkey.

Address for Correspondence/Yazışma Adresi: Atiye Oğrum MD, Tokat Gaziosmanpaşa University Faculty of Medicine, Department of Dermatology and Venereology, Tokat, Turkey Phone: +90 3562129500 E-mail: aogrum@yahoo.com Received/Geliş Tarihi: 06.07.2018 Accepted/Kabul Tarihi: 18.12.2018 ORCID: orcid.org/0000-0003-2999-2691

(c) Copyright 2019 by Turkish Society of Dermatology and Venereology

Turkderm-Turkish Archives of Dermatology and Venereology published by Galenos Yayınevi. 
the newborn. Here, we present a case with 37 weeks of pregnancy, who is considered to undergo cesarean section due the diagnosis of genital warts.

\section{Case Report}

Twenty-three years woman old with 37 weeks of primigravid pregnancy admitted to the hospital with the complaint of genital swelling. The medical history of the case showed that swelling was developed at $35^{\text {th }}$ weeks of pregnancy accompanying pain and burning sensation at the same area. Physical examination of the area showed multiple filiform papules, which are symmetrically located at the inner side of labia minor with a diameter of 1-2 mm, 1-3 mm long, and the same color with mucosa (Figure 1). The patient had no suspicious sexual contact. Acetowhitening was not detected after application of $5 \%$ acetic acid. Patient did not give permission to take a biopsy from the lesion. Therefore, the lesion was considered as VP after evaluating the findings obtained from the history, examination and acetic acid application. Spontaneous vaginal delivery was occurred at $39^{\text {th }}$ weeks of pregnancy. Written informed consent was obtained from the patient.

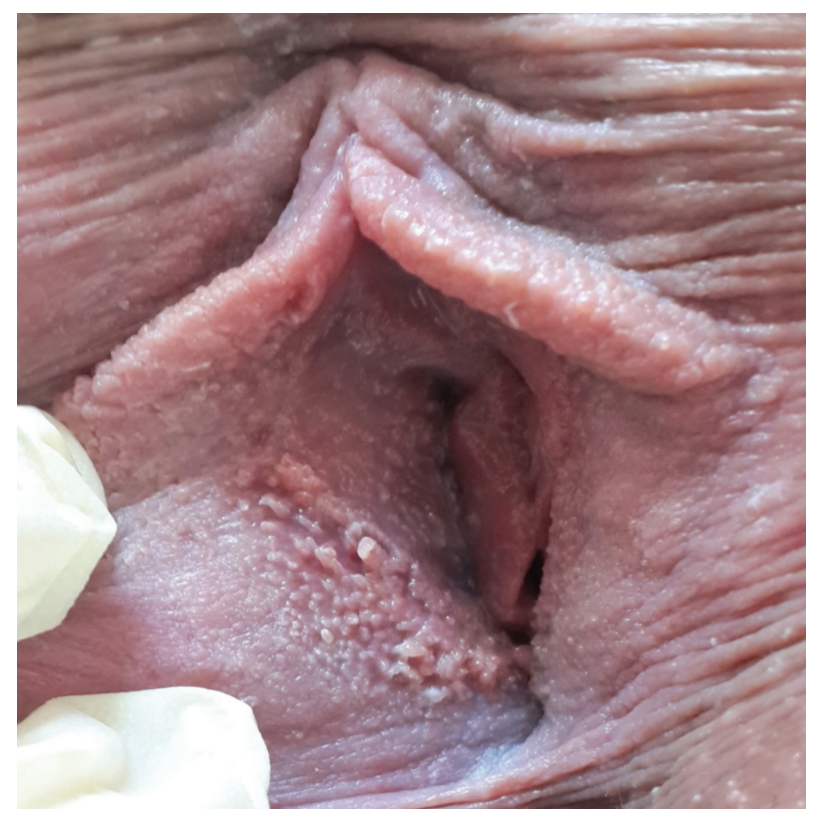

Figure 1. Multiple mucosa-colored filiform papules with linear and symmetrical distribution at the inner side of labia minora

\section{Discussion}

VP was firstly described as pseudocondyloma of vulva by Altmeyer et al. ${ }^{9}$ in 1981, and reported using various nomenclatures including hirsutoid papilloma of vulva, vulvar squamous papillomatosis, micropapillomatosis labialis, and squamous vestibular micropapilloma ${ }^{1-3,10,11}$. VP is considered as an entity associated with the elasticity of vulvar epithelium morphology ${ }^{3}$. Previously, HPV infection has been considered in the etiology, current techniques such as polymerase chain reaction and in situ hybridization revealed no association with HPV ${ }^{12,13}$. The clinical features of VP were defined by Moyal-Barracco et al. ${ }^{12}$. The clinical characteristics of VP papillomatosis and genital warts was shown on Table 1.

Lesions are usually asymptomatic, are pink, soft and filiform papules. Cases complaining various symptoms including itching, burning, stinging or pain have been reported ${ }^{1}$. In this case, the clinic symptoms were typical as burning and pain.

The histopathologic evaluation of VP shows finger-like extensions of fibrovascular tissue covered by vulvar epithelium. Vacuolated epithelial cells similar with koilocytes those occurred in some viral infections can be observed and this condition is caused by the vacuolization of epithelial cells containing high amounts of glycogen during tissue process $^{1,2}$.

National medical data showed four cases with $\mathrm{VP}^{11}$. The clinical features of the these cases with VP found are shown on Table 2.

One of the widest case series presented internationally was conducted by Mseddi et al. ${ }^{14}$ with eight cases. In this report, the ages of the patients ranged between 20 and 38, and seven of them were married.

\section{Table 1. The clinical characteristics of vestibular papilllomatosis and genital warts}

\begin{tabular}{|l|l|l|}
\hline $\begin{array}{l}\text { Clinical } \\
\text { feature }\end{array}$ & $\begin{array}{l}\text { Vestibular } \\
\text { papillomatosis }\end{array}$ & Genital warts \\
\hline Distribution & Symmetrical, linear array & Irregular \\
\hline Palpation & Soft & Hard \\
\hline Color & Pink, as adjacent mucosa & Flesh-colored, pink, gray \\
\hline Base & $\begin{array}{l}\text { Bases of individual } \\
\text { projections remain } \\
\text { separate }\end{array}$ & $\begin{array}{l}\text { Projections can coalesce } \\
\text { in a common base }\end{array}$ \\
\hline $\begin{array}{l}\text { Acetic acid } \\
\text { test }\end{array}$ & $\begin{array}{l}\text { No circumscribed } \\
\text { whitening }\end{array}$ & Circumscribed whitening \\
\hline Distribution & Symmetrical, linear array & Irregular \\
\hline Palpation & Soft & Hard \\
\hline
\end{tabular}

\section{Table 2. The clinical features of the cases with vestibular papillomatosis found in the national medical data}

\begin{tabular}{|l|l|l|l|l|l|l|}
\hline Study name & Case & Age & Marital status & $\begin{array}{l}\text { Circumstances of } \\
\text { discovery }\end{array}$ & Clinical examination & $\begin{array}{l}\text { Therapy for genital } \\
\text { warts misdiagnosis }\end{array}$ \\
\hline Bilgiç et al. ${ }^{11}$ & 1 & 43 & Married & Fortuitously & $\begin{array}{l}\text { Multiple filiform papules, linear } \\
\text { and symmetrically located at the } \\
\text { inner site of labia minor with the } \\
\text { same color with mucosa }\end{array}$ & - \\
\hline & 2 & 36 & $\begin{array}{l}\text { Pregnant } \\
(28 \text { weeks })\end{array}$ & Fortuitously & As in the case 1 & $\begin{array}{l}+ \text { (cryotherapy two years } \\
\text { earlier) }\end{array}$ \\
\hline & 3 & 37 & Married & Fortuitously & As in the case 1 & - \\
\hline & 4 & 32 & Married & Fortuitously & As in the case 1 & - \\
\hline
\end{tabular}


Four of the patients had a history of dermatology admission with a suspicion of genital warts. In addition, half of the cases had symptoms, two with vulvar pruritus and two with dyspareunia. Three of the cases were pregnant (16, 28 and 30 weeks). Lesions were incidentally detected in half of the patients by themselves or a gynecologist.

VP is considered as an anatomical variant of vulva, hence no need to treat. However, a few cases have been reported by gynecologists and dermatologists treated with podophylline or cryotherapy due to the misdiagnosis of genital warts podophyllin or cryotherapy due to the diagnosis of genital warts ${ }^{3}$. As a consequence of unnecessary treatment for the genital warts, anxiety may be observed in women associated with the possibility of cervical cancer risk or contamination of the baby.

$\mathrm{VP}$, a relatively frequent entity, should be kept in mind for the differential diagnosis of vulvar lesions thus leading to avoid unnecessary treatment and unwanted psychological effects on patients.

\section{Ethics}

Informed Consent: Written informed consent was obtained from the patient.

Peer-review: Externally peer-reviewed.

\section{Authorship Contributions}

Surgical and Medical Practices: A.O., H.Y.D., Concept: A.O., Design: A.O., Data Collection or Processing: A.O., H.Y.D., Analysis or Interpretation: A.O., Literature Search: A.O., Writing: A.O.

Conflict of Interest: No conflict of interest was declared by the authors.

Financial Disclosure: The authors declared that this study received no financial support.

\section{References}

1. Sarifakioglu E, Erdal E, Gunduz C: Vestibular papillomatosis: Case report and literature review. Acta Derm Venereol 2006;86:177-8.

2. Welch JM, Nayagam M, Parry G, Das R, Campbell M, Whatley J, et al: What is vestibular papillomatosis? A study of its prevalence, aetiology and natural history. Br J Obstet Gynaecol 1993;100:939-42.

3. Wollina $U$, Verma S: Vulvar vestibular papillomatosis. Indian J Dermatol Venereol Leprol 2010;76:270-2.

4. Van Beurden $\mathrm{M}$, van der Varge $\mathrm{N}$, de Craen AJ, Tjong-A-Hung SP, ten Kate FJ, ter Schegget J, et al: Normal findings in vulvar examination and vulvoscopy. Br J Obstet Gynaecol 1997;104:320-4.

5. Micheletti L, Preti M, Bogliatto F, Chieppa P: Vestibular papillomatosis Minerva Ginecol 2000;52:87-91.

6. Origoni M, Rossi M, Ferrari D, Lillo F, Ferrari AG: Human papillomavirus with co-existing vulvar vestibulitis syndrome and vestibular papillomatosis. Int J Gynaecol Obstet 1999;64:259-63.

7. Beznos G, Coates V, Focchi J, Omar HA: Biomolecular study of the correlation between papillomatosis of the vulvar vestibule in adolescents and human papillomavirus. ScientificWorldJournal 2006;6: 628-36.

8. De Deus JM, Focchi J, Stavale JN, de Lima GR: Histologic and biomolecular aspects of papillomatosis of the vulvar vestibule in relation to human papillomavirus. Obstet Gynecol 1995;86:758-63.

9. Altmeyer $\mathrm{P}$, Chilf GN, Holzmann $\mathrm{H}$ : Pseudocondylomata of the vulva. Geburtshilfe Frauenheilkd 1981;41:783-6.

10. Kıvanc-Altunay I, Aslan S, Çam Ö, Köşlü A, Başak T: Vestibular papillomatosis of the vulva. Turkderm 2000;3:177-9.

11. Bilgiç O, Karıncaoğlu Y, Akdogan Şahin N: Vulvar vestibuler papillomatosis. Turkderm 2012;46:220-2.

12. Moyal-Barracco M, Leibovitch M, Orth G: Vestibular papillae of the vulva. Lack of evidence for human papillomavirus etiology. Arch Dermatol 1990;126:1594-8.

13. Kakkar S, Sharma PK: Benign vulvar vestibular papillomatosis: An underreported condition in Indian dermatological literature. Indian Dermatol Online J 2017;8:63-5.

14. Mseddi M, Miladi S, Sellami Kh, Frikha F, Bahloul E, Masmoudi A, et al: Vestibular papillomatosis 8 cases series. Clin Exp Dermatol Ther 2018 